\title{
Civil Society Activisms in Democratic Governance Spaces: Entrenchment of Social Justice and Transformation in Post-Colonial Education Context
}

\author{
J Nyoni \\ Department of Educational Leadership and Management, South Africa. \\ Email: nyonij@unisa.ac.za \\ S Matlabe \\ Department of Adult Based Education and Training, South Africa. \\ Email: Matlasm@unisa.ac.za
}

Doi:10.5901/mjss.2014.v5n14p574

Abstract

The objective of this article was to explore the sudden waning of political and civic activism soon after gaining political dispensations in most of post-colonial African states with reference to South Africa. Findings indicated that community based organisations (CBOs) are led by leaders who are heavily laden with political influences that tend to blur the distinction between civic matters and political interests. We used the qualitative approach to analyse selected related literatures and empirical research. We argue that post-colonial civil societies in transitional democracies need to exert their roles and influences in governance structures, concentrating on the relationships between educational systems and forms of collective action, democracy and social citizenship, both within transitional societies and across key scales of political aggregation - local, national and transnational.

Keywords: Political aggregation, post-colonial societies, marriage of inconvenience, social citizenship, civic activism

\section{Introduction}

One of the often-raised questions concerning democratization and democratic consolidation is whether the elites or the public make and consolidate democracy. The role of political elites in nurturing democracy has been dealt with in many studies (Wucherpfennig and Welzel, 2009; Boix and Stokes, 2003; Lipset, 1959). Likewise for democratic consolidation, this, as our study suggests, depends on the emergence of a unified elitist group that commits itself to democratic rules by decentralizing power to social citizenry. In a constitutional democracy, the constitution is the most important statutory source of constitutional law. The South African Constitution (1996) contains fundamental prescripts that regulate the functions of state in a democracy. Prescripts may provide frameworks for the establishment of state and their functionaries, their powers and how they must exercise such powers. The state for example, as provided for in law, is obliged to involve the citizens in public school governance reform structures. The governance reform agenda includes: decentralization of educational management and financing; the involvement of parents and legal guardians in schoolbased management; the provision of better information on school performance and student achievement to parents and communities; the introduction of choice mechanisms (including demand-side mechanisms); and, the expansion of nongovernmental organizations (NGO), civil society (CS) and public-private service provision to stimulate competition and system reach.

CS could involve organized groups such as NGOs, trade unions and community-based organizations (CBOs). What seems to invite controversy is how civil society organizations should relate to government. It remains a contentious question in South Africa whether civil society should be "adversarial" or "complementary" to government. What this shows, however, is that the defining character of civil society has largely come to be based on how it relates to government.

\section{The Problem}

During the whole-school evaluation programme exercise, evidence revealed that approximately $80 \%$ of the schools in South Africa are essentially dysfunctional (Taylor, 2006b: 2). The South African Schools Act (Schools Act) gives formal 
effect to a participative form of democracy by redistributing power to local school governing bodies (SGBs) with the removal of centralised control over certain aspects of educational decision-making and the establishment of co-operative governance between education authorities and the school community (Squelch, 1998: 101; Oosthuizen, 2003:195). In principle these provisions were intended to establish a democratic power sharing, decentralisation and co-operative partnership among the state, parents (community members) and educators (Karlsson, 1998: 37).

\section{The Question}

Our article used the following question to explore the role of community based civic organisations in the promotion of governance in South African public schools:

"To what extent has civil society structures substantively contributed towards enabling environments for effective governance in South African public schools?"

\section{Objectives}

- Explore how civil society fulfils its function as a partner and agent in active participative democracy particularly in education provisioning at local level.

- To identify the kind of social contracts framed by - laws, regulations, policies, capacities and other factors fertile to encourage active civic participation in social projects.

\section{Contextualising Civil Society (CS) in South Africa}

Invariably, the concept of civil society (CS) is widely accepted in post-structural political science as an intermediary between the private sector and the state. Inferring that, CS is distinguished from the state and economic society, which includes profit-making going concerns, be they national or multi-national organisations. CS, as proffered by Diamond (1999) defines it, as "the realm of organized social life that is open, voluntary, bound by a legal order or set of shared rules". CS involves private citizens acting collectively to make demands to the state or to express in the public sphere their interests, preferences and ideas or to check the authority of the state and make it accountable. In our context CS may encompass a wide range of organizations concerned with public matters or demands. They include civic, issueoriented, religious, and educational interest groups and associations. Some are known as nongovernmental organizations, or NGOs; some are informal and loosely structured.

\section{South African Civil Society Organisations' Historical Context}

Civics have evolved in a complex and discontinuous way since their intensification in South Africa as was witnessed in the early 1980s in a country-wide growth in radical township-based local associations (including civics), the majority broadly sympathetic to the exiled African National Congress (ANC). The struggle for independence started way back since the arrival of colonialists in the seventeenth century. We however deliberately started our journey of analysis of the role of civil society organisations (CSOs) beginning from about 1983 taking into cognisance the intensification for the struggle against apartheid to about 2011.

In 1983 ANC-aligned associations came together under the banner of the United Democratic Front (UDF) to challenge reformed influx control measures, government-imposed Black Local Authorities (BLA) and the new tri-cameral national parliament which excluded Africans. UDF-linked civics played a prominent role in the 1984-1987 township uprisings until successive states of emergency drove many of them underground. From 1989 dormant civics reappeared and many new ones began to form, sometimes in areas, like African ethnic "homelands", where they had previously been absent. Swilling (1989) spoke of a "flowering" of the civic movement from this time.

In March 1992, some two years after the unbanning of the ANC and the year after the disbanding of the UDF, hundreds of ANC-sympathetic civics joined together in a South African National Civic Organisation (SANCO). SANCO aimed to give civics a presence in national-level constitutional negotiations and redistribute funds from better off to poorer civics, but its centralised character aroused intense controversy amongst some participating civics and grassroots activists.

The current discourse on "civil society" in Africa, conducted by Northern governments, international NGOs, activists and academics, often presents civil society as the locus sine qua non for progressive politics, the place where people 
organise to make their lives better, even a site of resistance. What is interesting in South Africa, compared to other African countries, is the number and calibre of CSOs geared towards doing precisely that - encouraging a popular commitment to procedural democracy. What is more, these kinds of CSOs feature predominantly in donor political aid programmes. In the course of our research we asked over a dozen different foreign donors what kind of civil society organisations they funded through their democracy assistance. There were five main categories: democracy organisations, concerned with the overall relationship between states and citizens; human rights and legal aid groups; conflict resolution agencies; organisations servicing or representing the nongovernmental sector; and think tanks.

\section{Theoretical Perspectives Underpinning Social Democracies}

John Locke (1632-1704) was the first in modern times to stress that civil society is a body in its own right, separate from the state. People form a community, in which their social life develops and in which the state has no say. This sphere is pre- or un-political. The first task of this civil society is to protect the individual-his/her rights and property-against the state and its arbitrary interventions (Merkel and Lauth 1998:4; Schade 2002: 10).

Political and social theorists have long argued that the development of mass systems of public education make an important contribution to the development and entrenchment of democracy - both through the socialization of citizens, and through the potentially redistributive function of equalizing educational opportunity. Yet despite its putative role in the formation of democratic politics, there has also been a significant reluctance on the part of educationalists and recent generations of social scientists to explore education as a legitimately political arena (Mundy, 2008). The origins and consolidation of mass systems of public education - and the normalization of the idea of education as a fundamentally public good - were clearly highly political processes. In some instances, (particularly European and Asia), mass schooling emerged as a top-down tool for state building independent of the introduction of formal democracy (Mundy, 2008).

The fact that compulsory, state-sponsored schooling emerged from "extremely heterogeneous legal frameworks and initial conditions" meant that mass education systems tended to develop around quite different sets of governance arrangements and allocative/redistributive expectations (Benavot and Resnick, 2004; Green, 1990; Green, Preston and Germen, 2006; Heidenheimmer, 1981, 1997; Archer, 1979). Educational systems emerged as more or less centralized (i.e., under central state control); and developed different organizational tiers or allocative "ladders", often in response to initial political conditions and contests. In many instances, middle-class support for the expansion of equal access to schooling hinged on the opening up of additional levels of publicly funded schooling (de Swann, 1988; Benavot and Resnick, 2004). The status quo tended to give false illusion to the masses that public schooling systems are the domain of the ruling elite and they must deliver without any cohesion from any quota. Ideally education provisioning should be a collective effort between the ruling elite and the masses and the latter must hold the executive to account.

\section{What is Civil Society?}

The first, which stemmed from the rise of anti-communist movements in Eastern Europe, views civil society as a source of state opposition (Seligman, 2002). This position grew out of the experiences in both Eastern Europe and Latin America over the past 30 years where grass-roots groups gained wide public momentum to overthrow repressive regimes (see Havel et al., 1996; Smolar, 1996). The second use of civil society emerged primarily out of North America as a backlash to liberal individualism. In this context, the concept refers to the communal and associational spaces of social life, which, it is argued, are necessary for a well-functioning democracy (Putnam, 1993; 1995; Walzer, 1995).

\section{Education as a Human Right}

Social democracies (primarily the Nordics), which have highly organized and secularized forms of collective political agency and well-developed leftist parties at the national level, have educational systems that are extremely well funded and, until quite recently, administratively centralized. These countries attain high levels of achievement and high equality of achievement in their educational systems, and they spend little on private provision. They also dedicate enormous resources to systems of income equalization and protection that limit economic inequality and guarantee a common standard of living. Yet a justification for social democracy is implicit in the United Nations Covenants on Human Rights, ratified by most of the world's countries. The covenants commit all nations to guarantee that their citizens shall enjoy the traditional formal rights; but they likewise pledge governments to make those rights meaningful in the real world by providing social security and cultural recognition to every person. 
The concept of a "public" - a whole polity that cares about the common good and has the capacity to deliberate about it democratically - is central to civil society thinking. The development of shared interests, a willingness to cede some territory to others, the ability to see something of oneself in those who are different and work together more effectively as a result - all these are crucial attributes for effective governance, practical problem-solving, and the peaceful resolution of our differences. In its role as the "public sphere", civil society becomes the arena for argument and deliberation as well as for association and institutional collaboration, and the extent to which such spaces thrive is crucial to democracy, since if only certain truths are represented, if alternative viewpoints are silenced by exclusion or suppression, or if one set of voices are heard more loudly than those of others, the "public" interest inevitably suffers. When all politics are polarized, public policy problems become embedded, even frozen, in polities that cannot solve them - think health care and welfare reform in the United States (US), for example. Breaking the resulting gridlock requires the creation of new publics in support of broad-based reform - exactly what is missing in the US right now.

Civil society organizations (or organized civil society), in partnership with government, play a major role not only in representing and voicing the views of communities but also in educating communities about what is due to them as citizens. This is a delicate area, often characterized by controversy about who should be responsible for representing the voiceless. As civil society organizations engage with government on numerous issues involving social justice and the wellbeing of society, tension often arises between the two role players (organized civil society and government) on what should really be on the table.

\section{Towards Effective Participatory Governance}

In Brazil, participatory governance was part of an effort to expand how, when and where citizens engage each other and engage the state. There was an explicit effort to use these spaces as the means to encourage the empowerment of citizens, to establish public deliberations, to include citizens' voices in decision making and, finally, to promote new state processes to implement citizens' demands. Participatory governance was thus not simply an institutional arrangement to select policies but it was designed to reinforce the democratic practices that were emerging from civil society. Civil society participation shifted during the 1990s and 2000s as the extensive, public demonstrations against the military government that marked the 1980s ceased to be an active part of the political environment. Instead, civil society activists repositioned themselves in the new participatory governance architecture in order to continue their efforts to empower citizens expand rights and hold local states accountable.

In the absence of a strong party system and in the presence of weak legislatures, participatory governance now occupies a crucial role funnelling demands emerging from organized communities into the executive branch.

\section{Methodology}

The qualitative research approach we adopted involved applying the concepts of complexity and reflexivity by pulling together multiple dimensions of social life in order to prepare and compile a concise narrative report on the state of civil society in South Africa particularly as regards the status of education. As a first step, we reviewed secondary data made available to us by the librarian using inclusion and exclusion criteria framed within the focus of our study. The review was comprehensive and sought to cover as wide a range of different data sources as possible. As a result of the review of existing information, an overview report on the state of civil society was prepared. The review of existing information also served to identify "data gaps" and, on that basis, to determine the nature and extent of primary research that we were intent of doing.

The second step dealt with the community sample research, carried out in three locations, namely Mpumalanga, Limpopo and Gauteng in South Africa. Participants included civil society stakeholders, experts and community members) with data from the "grassroots". It was, therefore crucial to bring in the voices and realities of civil society and "ordinary citizens" on the ground. The community sample research was designed as face-to-face semi-structured interviews where "ordinary" members of the community were asked about their involvement in civic matters and their experiences with CSOs in their community. Twenty (12) participants participated in three sessions of focus group discussion until data saturation. We were concerned with the role we were playing as agents as well as observers - how our observations influence what we were observing and how those who are observed influenced us. Data analysis and interpretations used the following two methods;

1. Typology - a classification system, taken from patterns, themes, or other kinds of groups of data. (Patton, 2002: 393 - 398; Lofland \& Lofland, 1995). Ideally, categories should be mutually exclusive and exhaustive if possible, often they aren't. Basically a list of categories example: Lofland and Lofland's, (1995) 1st edition list: 
acts, activities, meanings, participation, relationships and settings

2. Narrative Analysis (study the individual's speech) Reisman, (1993) Overlaps with other approaches. (Is it distinctive?) Discourse analysis looks at interaction, narrative is more individual)

The story is what a person shares about self. What you choose to tell frames how you will be perceived. Always compare ideas about self. Tend to avoid revealing negatives about self. Might study autobiographies and compare them.

- context-situation

- core plot in the story told about self

- basic actions

Narrative analysis could involve study of literature or diaries or folklore.

\section{Findings, Discussion, Recommendations and Conclusion}

Findings discussed below relate to analysed data obtained from participants' activists drawn from trade unions, consumer organisations, the formal and informal welfare sectors, non-governmental organisations (NGOs) and community-based organisations (CBOs), school governing bodies and teacher unions. The study focused on the role CSOs play in mobilising resources, both human and material, which enable educational institutions and programmes to function properly, such as adequately trained educators, school buildings, classrooms, furniture, teaching equipment, books and writing materials, as well as access to services like sanitation, water and electricity. Thematic findings are discussed hereunder.

\section{Conception of Civil Society Roles}

While community groups, churches and religious groups, the media or political interest groups have long played an important role on a local and national level, the findings indicated that proactive political alliance partners were increasingly involved with keep up appearances with the ruling part (African National Congress (ANC)) at the detriment of the problems besetting the communities in which they reside. Civil society discourse emanating from focus group discussions indicated that participants lacked deep or even superficial understanding of civic society roles as opposed to political preferences. A number of pronouncements from participants on their collective role in making public school improve their functions in providing quality education to their children reads:

It is the duty of the ANC to make sure that schools receive whatever assistance. If you speak out about problems outside the ANC structures you will not be recognised as a member of the school governing body. ANC started these structures and we joined them.

Civil society is largely perceived by the ANC-led government as an extension of its delivery capacity, and its role as an independent mechanism to challenge, contradict and influence policy has been largely overlooked. Some relationships between civil society activists and state entities were compromised due to adversarial and conflictual, while others will be more collaborative and collegiate

\section{Conflating Civil Society Roles with Politics}

The deterioration of the enabling environment generally causes a decline of civil society activity and makes postindependence revival difficult. Insecurity and fear, induced by years of apartheid subjugation, hinder people from participating, even in local community development as they are carefully observing the new power relations after the conflict (Pearce, 2005). This decline is also due to the fact that many civil society activists either form alliances with the ruling elite or join government structures thereby weakening the capacity of organizations that remain. The remaining civil society activists lamented:

"Reports of 120 and 180 learners in one classroom; at certain schools, parents are being asked to pay R240 a year for electricity costs at school; delegates reporting that learners at a school cleaning school, not in class, told principal, nothing done; one school reported that there is no furniture at the school - no desks, nothing!! Learners are sitting on the floor."

All activists adapt to the difficult environment and new power relations. Especially when the state is weak, the influence of uncivil, xenophobic or mafia-like groupings tends to become stronger (Belloni 2006: 8-9), thus curtailing 
significantly the potential influence of civil society groups working for cross-ethnic understanding. Participants were arguing about what the government of the day was doing to the quality of education instead of debating better ways of making government accountable and responsive to their local needs. The antagonistic tendencies enhances the danger that civil society groups develop into uncivil actors, due to conflict and aggravated by economic decline, social stress, ubiquitous existence of violence and separation of civil society along political lines (Schmidt, 2003: 323-4).

\section{Detoxification of Apartheid Related Violence Psyche}

Fanon (2004) remains one of the most serious and dialectical theorists of national liberation. His critique of the nationalist project and proclamation that "the single party is the modern form of the dictatorship of the bourgeoisie" is strangely applicable to the African National Congress (ANC) (Fanon, 1967b:186). Fanon (2004: 142) states that nationalism was useful to rouse the masses against the oppressor, but it falls apart in the aftermath of independence in the absence of a broader social and political consciousness. Nationalism must very quickly be "explained, enriched, and deepened... [then turned] into a social and political consciousness, into humanism" to avoid reaching a dead end. Falon's (2004) undergirds what some participants clearly stated:

The problems in public schools today are as the results of years of neglect by the previous apartheid government. Our government (sic) is trying its best to sort out the mess it inherited from apartheid government.

The service delivery challenges are never the fault of the nationalist government but that of former colonial regimes. As Fanon (2004) proposes that post-colonial citizens need what he calls "collective consciousness" to begin to take control of their destiny and those of others without relying on the state's benevolence. He describes a "collective consciousness," "enlightened and coherent praxis," and "collective forging of a destiny" that is totalizing and complete, that restores human dignity, and that works towards a new, international, liberated human. This can be achieved by detoxing all mental retrogressive and brutal apartheid shackles, by embedding in their consciousness the realia that independence ushers in a sense of self-respect, dignity and hard work.

\section{Civic Education in Community Empowerment on Good Governance}

They must know enough about the basic features of a democratic political system to be able to access it when their interests are at stake, and they must believe in the importance of certain key democratic values, such as tolerance for divergent viewpoints and support for the rule of law. They must also be willing and able to participate in local and national politics, and they must believe that their participation is important to the continued viability of the democratic political system. In most mature democracies, citizens have had the opportunity to absorb democratic beliefs and practices over a lifetime. As they participate in family and neighbourhood life, join local organizations, move through the educational system, and are exposed to a free and independent media, citizens have the opportunity to absorb and practice the basic norms of a democratic culture.

What we know are political meetings and we will always protest until the ANC understands our grievances. We have all the rights to exercise (sic) rights in a democracy

\section{Civic Intelligence Involve Intellectual and Participatory Dexterities}

The second essential component of civic education in a democratic society is civic skills. If citizens are to exercise their rights and discharge their responsibilities as members of self-governing communities, they not only need to acquire a body of knowledge such as that embodied in the five organizing questions just described; they also need to acquire relevant intellectual and participatory skills.

Intellectual skills in civics and government are inseparable from content. To be able to think critically about a political issue, for example, one must have an understanding of the issue, its history, its contemporary relevance, as well as command of a set of intellectual tools or considerations useful in dealing with such an issue.

\section{Discussion}

Gandhi became famous by fighting for the civil rights of Muslim and Hindu Indians in South Africa, using the new techniques of non-violent civil disobedience that he developed. The techniques he used were a turning point in his life 
and shaped his social activism and awakened him to social injustice. After witnessing racism, prejudice and injustice against Indians in South Africa, Gandhi began to question his place in society and his people's standing in the British Empire. We use Ghandi's methods of resistance to illustrate our contention that post 1994 Ghandi's philosophy is still relevant in South Africa. Communities in South Africa are still in the pre-independence violent protests mode that left many freedom activists psychologically, emotionally, spiritually, socially and physically ruined. The impact of such experiences makes it difficult for them to realise that they are now free and it is time for them to take charge of their way forward by detoxing the remnants of apartheid suppressive practices.

\section{Use of Nonviolence in Protests}

The culture of violence was entrenched in South African's psyche through the armed struggle and violent protests against Apartheid. As a result the violent culture continues to mar civilised and genuine all forms of protests in South Africa that seek government of the day to be accountable, abide by the rule of law and justice at any level of government. Our findings indicate that there is need to restore mutual respect between individuals. There is need for peace in place of conflict, forgiveness in place of enmity, reconciliation in place of division, acceptance in place of rejection, confidence in place of fear, faith in place of doubt, joy in place of sorrow, and hope in place of despair.

In this reality, the scope of interests advanced collectively in the public sphere, and the methods used by those actors, are very broad and include democratic, progressive and civil interests and methods as well as undemocratic, fundamentalist and uncivil ones, such as violent demonstrations, continued hate speeches by the political leadership in South Africa, and deal-striking behind closed doors.

Strategies for political education to build this consciousness include public information campaigns, and meetings amongst the masses that offer a space for people to speak, express themselves, innovate. In such gatherings, the cross pollination of ideas and eyes discover a wider human panorama. Amidst this new humanism, people live and work "with one's brain and one's heart [more] than with muscles and sweat" (Fanon, 2004) He condemns language only comprehensible to law and economic graduates that both confuse and convey an unspoken desire of the intellectual to "dispossess" (Fanon, 2004).

\section{Self-Reliant Social Contract}

Rousseau (1988) grinned over man's departure from the state of nature and his consequent preoccupation with artificial social customs and institutions-all derived from vain and illusory desires to dominate others. Although he accepted individual or innate differences among human beings, Rousseau (1988) attacked the existence of social and civil inequalities in which people crushed the spirits of others in attempting to control them. He concluded society had tarnished the purity of human nature, fuelled by a quest to rule over others, and made man a tyrant over nature and himself. African socialists were nationalist-politicians who believed the anthropologically problematic idea of a longestablished ethos within the pre-colonial community's traditions of extended family networks of social mutualism, social egalitarianism, and a consensus system of political order. However African socialism became a consensus metaphor for failure - of the centralization, authoritarianism, and inefficiencies of state malfunction. What is needed today is a social pact that wrestles power from the ruling elite by the ordinary citizens so that they remain in control and use it for checks and balances in order to hold the ruling class accountable.

\section{Recommendations}

While community protests have brought wide-spread attention to the acute gaps in delivery on basic services, the protests have also highlighted other critical weaknesses in local government, including weak leadership, lack of accountability and transparency, poorly capacitated administrative systems and a blurring of boundaries between political and civic structures communities have remained paralysed and unable to react to challenges faced by public schools. Izimbizo, ward committees and participation in civic or CBOs are appropriate forums where members of the communities can engage each other where;

- Adult education programmes can play a major role in teaching people on how to take more responsibility for themselves and for each other and for finding their own solutions to local concerns.

- local people practice democratic engagement through local organizations and where wider political engagement is fostered and nurtured.

- Stronger bonds between neighbours, where friendly relations build trust and a mutual support network and 
prevent social isolation.

- relationships between diverse groups are strengthened and the risk of social breakdown is minimized.

- $\quad$ local people come together to participate and contribute to a vibrant community life.

\section{Conclusion}

The development of mass systems of public education make an important contribution to the development and entrenchment of democracy - both through the socialization of citizens, and through the potentially redistributive function of equalizing educational opportunity. According to Buccus, Hemson, Hicks and Piper (2007: 3), public participation is essential in any society as it enhances development and service delivery. Participation is also necessary because it deepens the process of democracy as well as makes government more effective and accountable. As Ballard (2008: 170) notes, "where citizens themselves are able to influence decisions, the imperative of addressing suffering becomes far stronger and more direct". Constructive collective engagements on issues that affect local people in public fora organized by CBOs can only serve to strengthen civic activism to take charge of their lives without depending on the benevolence of the political elite.

Thus, emancipation according to Lipset (1959) manifests itself largely through changing social conditions that foster a democratic culture. Stronger in human capital, especially education, and exposed to wider and more diverse audiences (e.g., within voluntary associations), people in developed countries are more receptive towards democratic values of tolerance and less so towards regime-hostile ideologies (Lipset, 1959: 84). This is especially true when people are granted economic and political rights through social contacts that they can begin to assume responsible behaviour towards preserving their social projects.

\section{References}

Ballard, R. (2008). Between the Community Hall and the City Hall: Five Research Questions on Participation. Transformation. 6 (7): 66 67.

Boix, C and Stokes, S. (2003). Endogenous Democratization. World Politics. 5 (5): 517-549,

Buccus, I., Hemson, D., Hicks, J and Piper, L. (2007). Public Participation and Local Governance. Research Report prepared by The Centre for Public Participation, in association with Human Sciences Research Council and the University of KwaZulu-Natal.

Diamond, L. (1999). Development Democracy: Toward Consolidation, Baltimore: The Johns Hopkins University Press.

Karlsson, J. (2002). The role of democratic governing bodies in South African schools. Comparative Education, 3 (8): 327-336.

Lipset, SM. (1959). Some Social Requisites of Democracy: Economic Development and Political Legitimacy. American Political Science Review. 53 (3): 69-105,

Lofland, J and Lofland, LH. (1995). Typological Systems: Analyzing social settings, 3rd ed.

Belmont, Cal.: Wadsworth.

Oosthuizen, IJ (ed.) (2003). Aspects of Education Law, 3rd edn. Pretoria: Van Schaik Publishers.

Patton, MQ. (2002). Qualitative Research and Evaluation methods. International Educational and Professional Publisher, Thousand Oaks, London: Sage Publications.

Putnam, RD. (1993). Making Democracy Work: Civic Traditions in Modern Italy. Princeton NJ: Princeton University Press.

Putnam, RD. (1995). "Bowling Alone: America's Declining Social Capital", Journal of Democracy, 6 (1): 65-78.

Ranchod, K. (2007). State-Civil Society Relations in South Africa: Some Lessons from Engagement. Centre for Policy Studies. Johannesburg

Reisman, CK. (1993). Narrative analysis. Newbury Park, Cal.: Sage.

Rousseau, J. (1988). The social contract (1762), trans. George Douglas Howard Cole. Buffalo, NY: Prometheus.

Seligman, AB. (2002). "Civil Society as Idea and Ideal", in W. Kymlicka (ed.), Alternative Conceptions of Civil Society. Princeton NJ: Princeton University Press.

Simon, WH. (1999). "Three Limitations of Deliberative Democracy", in S. Macedo (ed.), Deliberative Politics. Oxford: Oxford University Press, pp. $49-57$.

Smolar, A. (1996). "From Opposition to Democracy", Journal of Democracy, 7 (1): 26-38.

Squelch, JM. (1998). The establishment of new democratic school governing bodies: co-operation or coercion. In: De Groof J, Bray E, Mothata S \& Malherbe R (eds). Power-sharing in Education: Dilemmas and implications for Schools. Leuven: Acco.

Taylor, N. (2006b). Accountability and support in school development in South Africa. Paper presented to the 4th Sub-regional Conference on Assessment in Education hosted by Umalusi, Pretoria, 26-30 June.

Walzer, M (ed.) (1995). Toward a Global Civil Society. Oxford: Berghahn Books.

Wucherpfennig, J and Deutsch, F. (2009). Modernisation and Democracy: Theories and evidence. Living Reviews in Democracy. 1 (1): $47-72$ 